DOI : http://dx.doi.org/10.33578/jpfkip.v9i4.7995

ISSN : 2303-1514 | E-ISSN : 2598-5949

https://primary.ejournal.unri.ac.id/index.php/JPFKIP

\title{
META-ANALYSIS OF THE EFFECT OF MAKE A MATCH LEARNING MODEL ON PRIMARY SCHOOL STUDENTS LEARNING OUTCOMES
}

\author{
Lahma Ainun Sajidah ${ }^{1}$, Mohammad Taufiq ${ }^{2}$, Muhammad Thamrin ${ }^{3}$, Sri Hartatik ${ }^{4}$ \\ ${ }^{1,2,3,4}$ Universitas Nahdlatul Ulama Surabaya \\ 는ama.ainun1485@gmailcom, ${ }^{2}$ mtaufiq79@unusa.ac.id, ${ }^{3}$ pmksthamrin@gmail.com, ${ }^{4}$ titax@unusa.ac.id
}
META-ANALISIS PENGARUH MODEL PEMBELAJARAN MAKE A MATCH TERHADAP HASIL BELAJAR SISWA SEKOLAH DASAR

\begin{tabular}{|c|c|}
\hline ARTICLE INFO & ABSTRACT \\
\hline \multirow[t]{2}{*}{$\begin{array}{l}\text { Submitted: } \\
\text { 01 Juli } 2020 \\
1^{\text {st }} \text { July } 2020\end{array}$} & $\begin{array}{l}\text { Abstract: This study aims to determine the effect of the Make a Match learning model on learning } \\
\text { outcomes of primary school students. The method used in this research was meta-analysis method. This } \\
\text { study was to determine whether the Make a Match learning model can improve student learning } \\
\text { outcomes. The data were collected through relevant article. The data was obtained from online journal } \\
\text { searches through Google Scholar, where } 10 \text { articles were obtained. The keywords used are "Make a } \\
\text { Match learning model" and "learning outcomes". Data were obtained and re-analyzed using } \\
\text { quantitative methods. Based on the results of the analysis, there was an effect of the Make a Match } \\
\text { learning model on student learning outcomes with an average after being given treatment that was } \\
46.946 \text { with an average before being given treatment that was 35.963. So it can be concluded that there } \\
\text { is an effect of the Make a Match learning model on the increase in student learning outcomes, namely } \\
\text { 10.983. }\end{array}$ \\
\hline & Keywords: make a match, learning model, learning outcomes \\
\hline \multirow[t]{3}{*}{$\begin{array}{l}\text { Accepted: } \\
21 \text { Agustus } 2020 \\
21^{\text {st }} \text { August } 2020 \\
\text { Published: } \\
30 \text { Agustus 2020 } \\
30^{\text {th }} \text { August } 2020\end{array}$} & $\begin{array}{l}\text { Abstrak: Penelitian ini bertujuan untuk mengetahui pengaruh model pembelajaran Make a Match } \\
\text { terhadap hasil belajar siswa sekolah dasar. Metode yang digunakan dalam penelitian ini adalah } \\
\text { metode meta analisis. Penelitian ini untuk mengetahui apakah jika diterapkan model pembelajaran } \\
\text { Make a Match dapat meningkatkan hasil belajar siswa. Pada tahap selanjutnya mengumpulkan artikel } \\
\text { yang relevan untuk mengumpulkan data. Data tersebut diperoleh penelurusan jurnal online melalui } \\
\text { Google Scholar dimana diperoleh sebanyak } 10 \text { artikel. Kata kunci yang digunakan yaitu "model } \\
\text { pembelajaran Make a Match" dan "hasil belajar". Data diperoleh dan dianalisis kembali } \\
\text { menggunakan metode kuantitatif. Berdasarkan hasil analisis terdapat pengaruh model pembelajaran } \\
\text { Make a Match terhadap hasil belajar siswa dengan rata-rata setelah diberi perlakuan yaitu } 46.946 \\
\text { dengan rata-rata sebelum diberi perlakuan yaitu 35.963. Sehingga dapat disimpulkan bahwa terdapat } \\
\text { pengaruh model pembelajaran Make a Match terhadap meningkatnya hasil belajar siswa yaitu sebesar } \\
\text { 10.983. }\end{array}$ \\
\hline & Kata kunci: model pembelajaran make a match, hasil belajar \\
\hline & 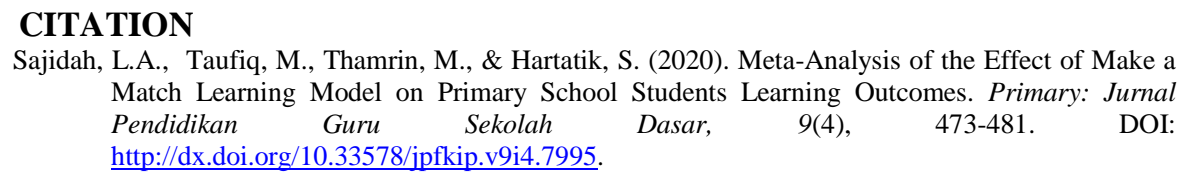 \\
\hline
\end{tabular}

\section{PENDAHULUAN}

Pendidikan merupakan hal yang sangat penting dalam kehidupan manusia. Salah satu tujuan pendidikan yaitu penanaman pengetahuan dan keterampilan sebagai bagian dari satu generasi ke generasi berikutnya. Salah satu cara untuk mencapai tujuan pendidikan yang baik adalah 
dengan menerapkan pendekatan belajar dalam proses kegiatan belajar mengajar. Dalam proses pembelajaran siswa dapat mengembangkan potensi dirinya untuk memiliki kekuatan spiritual keagamaan, pengendalian diri, kepribadian, kecerdasan, akhlak mulia, serta keterampilan yang diperlukan oleh dirinya, masyarakat, bangsa dan negara. Untuk tercapainya tujuan pendidikan yang dimaksud, tidak terlepas dari kegiatan pembelajaran dengan guru sebagai peran utama (Anggarawati, 2014: 2). Karena itu guru harus mampu menciptakan pembelajaran yang inovatif agar tercipta suasana belajar yang menyenangkan dan guru dapat menggunakan model atau metode pembelajaran yang dapat menghendaki keterlibatan dan peran aktif siswa dalam pengamatan, menerapkan konsep dan mengomunikasikan atau yang disebut dengan pembelajaran aktif.

Pembelajaran yang aktif adalah adanya interaksi antara guru dan siswa, interaksi yang dimaksud yaitu hubungan timbal balik antara guru dan siswa, siswa dan guru, siswa dan siswa lainnya (Susanto, 2013: 53). Selain itu perlu adanya model pembelajaran yang disesuaikan dengan kebutuhan di kelas yang bertujuan untuk memungkinkan siswa lebih tertarik untuk belajar serta dapat belajar secara aktif dan menyenangkan sehingga siswa dapat meraih hasil belajar yang optimal.

Satu diantara model pembelajaran yang bisa digunakan untuk meningkatkan hasil belajar siswa adalah model pembelajaran Make a Match, merupakan model pembelajaran di mana dalam kegiatannya siswa diinstruksikan untuk bekerja sama mencari pasangan mengenai suatu konsep dalam suasana yang menyenangkan. Adapun langkah-langkah dari model pembelajaran Make a Match menurut Berlin (2015) adalah (1) guru menyiapkan beberapa kartu yang berisi konsep atau topik yang cocok untuk sesi review, dimana terdapat kartu soal dan kartu jawaban, (2) setiap siswa mendapatkan kartu yang bertuliskan soal dan jawaban, (3) setiap siswa memikirkan jawaban atau soal dari kartu yang dipegang, (4) setiap siswa mencari pasangan kartu yang cocok dengan kartunya, (5) setiap siswa yang dapat mencocokkan kaertunya sebelum batas waktu akan diberi poin, (6) jika siswa tidak dapat mencocokkan kartunya dengan kartu temannya (tidak dapat menemukan kartu soal dan kartu jawaban) akan mendapat hukuman, yang telah disepakati bersama, (7) setelah satu babak, kartu dikocok lagi agar tiap siswa mendapat kartu yang berbeda dari sebelumnya, demikian seterusnya.

Model pembelajaran Make a Match dapat digunakan untuk mempengaruhi tingkat partisipasi belajar siswa dalam mengikuti proses pembelajaran dan dapat mengukur penguasaan siswa terhadap materi yang disampaikan, khususnya dalam pemahaman konsep. Siswa dapat mengembangkan kemampuan berpikirnya masingmasing walaupun belajar dalam konteks bermain dan bekerja sama. Kelebihan model pembelajaran Make a Match adalah siswa lebih aktif, bahkan dengan model ini siswa yang pasif harus berpindah tempat duduk untuk mencari pasangan (Kadek, Gede \& Made 2017: 3).

Adapun teori yang mendukung model pembelajaran Make a Match yaitu teori belajar menurut Vygotsky. Menurut Vygostky pembelajaran terjadi apabila anak bekerja atau belajar menangani tugas-tugas yang belum dipelajari namun tugas-tugas itu masih dalam jangkauan kemampuannya, atau tugas-tugas tersebut berada dalam zone proximal development. Zone proximal development (ZPD) didefinisikan sebagai jarak antara level perkembangan aktual yang ditentukan melalui pemecahan masalah secara mandiri dan level potensial perkembangan yang ditentukan melalui pemecahan dengan bantuan orang dewasa atau dengan kerja sama dengan teman sebaya yang lebih mampu (Susanto, 2013:97).

Berdasarkan hasil observasi yang sudah dilaksanakan pada kelas IV salah satu sekolah dasar di Surabaya, guru terkadang menggunakan model atau media saat proses pembelajaran. Penggunaan model atau media pembelajaran disesuaikan dengan materi. Meskipun begitu belum menunjukkan peningkatan yang signifikan terhadap hasil belajar siswa khusunya mata pelajaran IPA. Survey tersebut dilakukan pada kelas IV yang memiliki jumlah siswa 32, dengan siswa yang belum tuntas sebanyak 19 dan siswa yang tuntas dengan sebanyak 13. Berdasarkan wawancara dengan guru diperoleh data presentase siswa belum tuntas sebesar $59.37 \%$ atau sebanyak 
19 siswa dan $40.62 \%$ lainnya atau sebanyak 13 siswa yang tuntas dari jumlah keseluruhan.

Berbagai penelitian terdahulu menunjukkan terdapat pengaruh terhadap hasil belajar siswa setelah diterapkan model pembelajaran Make a Match, salah satunya adalah penelitian oleh Halimatun Nisa yang berjudul "Pengaruh Model Pembelajaran Cooperative Learning Tipe Make A Match Terhadap Hasil Belajar Siswa Kelas IV Pada Mata Pelajaran IPA Di Min 1 Kec. Padang Hulu Kota Tebing Tinggi Tahun Ajaran 2018/2019". Dimana pada hasil akhir menunjukkan terdapat pengaruh yang signifikan setelah diterapkan model pembelajaran Make a Match terhadap kelas eksperimen yaitu dengan nilai sebesar 83.833, sedangkan pada kelas kontrol dengan nilai sebesar 70.667 .

Keberhasilan siswa dalam belajar tergantung pada kemampuan guru yang profesional. Guru yang profesional adalah guru yang yang memiliki kompeten dalam bidangnya menguasai dengan baik bahan yang akan diajarkan serta mampu memilih model ataupun metode belajar mengajar yang tepat sehingga pendekatan itu bisa berjalan dengan baik. Serta suasana pengajaran yang tenang, terjadinya dialog yang

\section{METODE PENELITIAN}

Jenis penelitian ini merupakan penelitian dengan teknik meta analisis. Pengertian meta analisis secara sederhana dapat diartikan sebagai analisis atas analisis. Sifat dari meta analisis adalah kuantitatif. Penelitian ini mengkaji sejumlah penelitian dalam masalah yang sejenis, dimana data tersebut berasal dari studi primer. Hasil analisis dari studi primer tersebut akan di pakai sebagai dasar untuk menerima atau mendukung hipotesis dan menolak atau menggugurkan hipotesis yang diajukan oleh beberapa peneliti (Saryono \& Ahmad, 2011: 149). Pengumpulan data dilakukan dengan cara menelusuri jurnal menggunakan google schoolar. Kata kunci yang

\section{HASIL DAN PEMBAHASAN}

Dari hasil pengolahan data pada 10 artikel ilmiah di ambil dari jurnal ilmiah dan google kritis antara siswa dengan guru, dan menumbuhkan suasana yang aktif di antara siswa tentunya akan memberikan nilai lebih pada proses pengajaran. Sehingga keberhasilan siswa dalam belajar dapat meningkat secara maksimal (Susanto, 2013:17).

Hasil belajar merupakan suatu puncak dari proses pembelajaran. Hasil belajar berkat evaluasi guru dan juga merupakan suatu interaksi tindak mengajar dan tindak belajar. Dari sisi guru tindak mengajar diakhir proses evaluasi belajar. Sedangkan dari sisi siswa, hasil belajar merupakan puncak proses belajar. Ada dua faktor yang mempengaruhi hasil belajar, yaitu:(1) faktor internal (faktor yang bersumber dari dalam diri peserta didik) meliputi kecerdasan, minat dan perhatian, motivasi belajar, ketekunan, sikap, kebiasaan belajar, serta kondisi fisik dan kesehatan. (2) faktor eksternal (faktor yang berasal dari luar diri peserta didik) meliputi keluarga, sekolah, dan masyarakat (Masa, 2017:4).

Berdasarkan permasalahan tersebut, maka tujuan penelitian yang dilakukan adalah untuk mengetahui apakah terdapat pengaruh model pembelajaran Make a Match terhadap hasil belajar siswa jika diterapkan di sekolah dasar yang berbeda-beda.

digunakan dalam pencarian yaitu "model pembelajaran Make a Match" dan "hasil belajar". Penelusuran artikel dimulai dari tahun 2013 sampai 2020 dengan menggunakan siswa sekolah dasar sebagai subjek yang diteliti. Analisis yang digunakan dalam penelitian ini adalah pengaruh model pembelajaran Make a Match terhadap hasil belajar siswa dan kategori yang digunakan yaitu nilai sebelum dan sesudah diterapkan model pembelajaran Make a Match. Selanjutnya nilai sebelum dan sesudah diterapkan model pembelajaran Make a Match tersebut di analisis dengan mencari rata-rata.

schoolar. Data yang diperoleh pada 10 artikel akan dibulatkan dan diolah menggunakan SPSS versi 25 


\section{PRIMARY : JURNAL PENDIDIKAN GURU SEKOLAH DASAR \\ Volume 9 Nomor 4 Agustus 2020 \\ DOI : http://dx.doi.org/10.33578/jpfkip.v9i4.7995 \\ ISSN : 2303-1514 | E-ISSN : 2598-5949 \\ https://primary.ejournal.unri.ac.id/index.php/JPFKIP}

for windows. Data yang digunakan dalam penelitiann ini sangat luas sehingga data tersebut diolah dengan cara merangkum dan diambil inti dari artikel, setelah itu data yang telah didapat akan dihitung secara kuantitatif dan kualitatif. Hasil analisis model pembelajaran Make a Match menggunakan hasil analisis uji Paired Samples $T$ Test yang dapat dilihat pada tabel dibawah ini.

Tabel 1. Hasil Analisis Model Pembelajaran Make a Match

\begin{tabular}{|c|c|c|c|c|c|c|}
\hline \multirow{2}{*}{ No } & \multirow{2}{*}{ Judul Penelitian } & \multirow{2}{*}{ Topik Penelitian } & \multirow{2}{*}{ Peneliti } & \multicolumn{3}{|c|}{ Peningkatan Hasil Belajar } \\
\hline & & & & Sebelum & Sesudah & Gain \\
\hline 1. & $\begin{array}{l}\text { Keefektifan Model Make a } \\
\text { Match Dalam Pembelajaran } \\
\text { Matematika Siswa Kelas VI } \\
\text { Sekolah Dasar }\end{array}$ & $\begin{array}{l}\text { Keefektifan, Make a } \\
\text { Match, } \\
\text { Pembelajaran } \\
\text { Matematika }\end{array}$ & $\begin{array}{l}\text { Andi } \\
\text { Kaharuddin }\end{array}$ & 50 & 82.4 & 32.4 \\
\hline 2. & 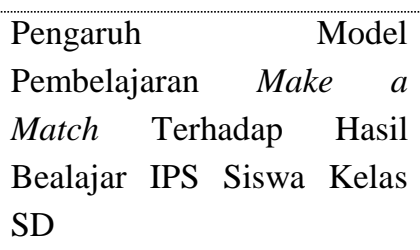 & $\begin{array}{l}\text { Make a Match, } \\
\text { Hasil Belajar }\end{array}$ & $\begin{array}{l}\text { Nym. Masa, } \\
\text { Nym. Murda, } \\
\text { Luh Pt. Putrini } \\
\text { Mahadewi }\end{array}$ & 18.25 & 24 & 5.75 \\
\hline 3. & $\begin{array}{l}\text { Pengaruh } \\
\text { Pembelajaran Kooperatif } \\
\text { Tipe Mencari } \\
\text { (Make a Match) } \\
\text { Hasil Siswa Perhadap } \\
\text { IPA Pokok Bahasan Benda } \\
\text { dan Sifatnya Kelas V SD } \\
\text { Negeri 1 Weru Kidul } \\
\text { Kecamatan } \\
\text { Kabupaten Cirebon }\end{array}$ & $\begin{array}{l}\text { Hasil belajar, } \\
\text { Mencari pasangan, } \\
\text { Make a Match }\end{array}$ & $\begin{array}{l}\text { Arbiyah, Yati } \\
\text { dan Gita } \\
\text { Erlangga } \\
\text { Kurniawan }\end{array}$ & 63.50 & 80.25 & 16.75 \\
\hline 4. & $\begin{array}{lr}\text { Pengaruh } & \text { Model } \\
\text { Pembelajaran } \quad \text { Kooperatif } \\
\text { Tipe Make a Match } \\
\text { Terhadap Hasil Belajar } \\
\text { Siswa Pada Mata Pelajaran } \\
\text { IPA }\end{array}$ & $\begin{array}{l}\text { Model Pembelajaran } \\
\text { Tipe Kooperatif } \\
\text { Make a Match, } \\
\text { Hasil Belajar }\end{array}$ & $\begin{array}{l}\text { Alfiyaturrizqi } \\
\text { Nadliyah, } \\
\text { Mohammad } \\
\text { Taufiq, } \\
\text { M.Thamrin } \\
\text { Hidayat dan } \\
\text { Suharmono } \\
\text { Kasiyun }\end{array}$ & 16.40 & 24.60 & 8.2 \\
\hline 5. & 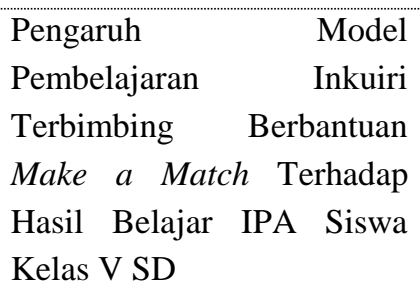 & $\begin{array}{l}\text { Hasil Belajar IPA, } \\
\text { Inkuiri Terbimbing, } \\
\text { Make a Match }\end{array}$ & $\begin{array}{l}\text { Made } \\
\text { Suarjana, } \\
\text { Gede } \\
\text { Margunayasad } \\
\text { an Nyoman } \\
\text { Kusmariyatni }\end{array}$ & 21.23 & 25.85 & 4.62 \\
\hline 6. & $\begin{array}{l}\text { Pengaruh } \\
\text { Pembelajaran } \quad \text { Make } \quad a\end{array}$ & $\begin{array}{l}\text { Make a Match, } \\
\text { Hasil Belajar }\end{array}$ & $\begin{array}{ll}\text { Aditya } & \text { Ayu } \\
\text { Perdana } & \end{array}$ & 75.83 & 85.89 & 10.06 \\
\hline
\end{tabular}




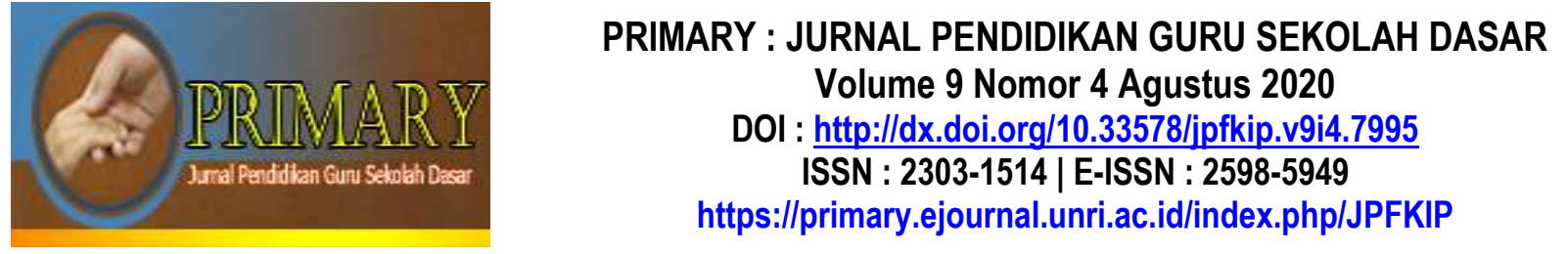

\begin{tabular}{|c|c|c|c|c|c|c|}
\hline & $\begin{array}{llr}\text { Match } & \text { Terhadap } & \text { Hasil } \\
\text { Belajar } & \text { Siswa Kelas } & \text { IV } \\
\text { SDN } & \text { Semolowaru } & \text { I } \\
\text { Surabaya } & & \end{array}$ & & & & & \\
\hline 7. & 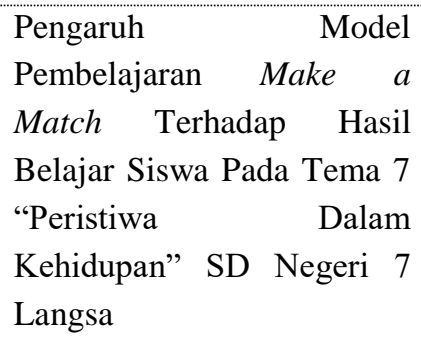 & $\begin{array}{l}\text { Make a Match, } \\
\text { Model } \\
\text { Pembelajaran, Hasil } \\
\text { Belajar }\end{array}$ & $\begin{array}{l}\text { Debby } \\
\text { Anggia, } \\
\text { Asnawi dan } \\
\text { Juliati }\end{array}$ & 64.11 & 78.23 & 14.12 \\
\hline 8. & $\begin{array}{l}\text { Pengaruh } \\
\text { Pembelajaran } \quad \text { Kooperatif } \\
\text { Tipe Make a Match } \\
\text { Berbantuan Audio Visual } \\
\text { Terhadap Hasil Belajar IPS } \\
\text { Sekolah Dasar }\end{array}$ & $\begin{array}{l}\text { Make a Match, } \\
\text { Audio Visual, Hasil } \\
\text { Belajar, IPS }\end{array}$ & $\begin{array}{lr}\text { Ketut } & \text { Gading } \\
\text { dan } & \text { Kadek } \\
\text { Dian } & \\
\text { Kharisma }\end{array}$ & 15.00 & 23.28 & 8.28 \\
\hline 9. & $\begin{array}{lr}\text { Pengaruh } & \text { Model } \\
\text { Pembelajaran } & \text { Kooperatif } \\
\text { Make a Match } & \text { Berbantuan } \\
\text { Media Benda Asli Terhadap } \\
\text { Hasil Belajar Matematika } \\
\text { Siswa Kelas IV }\end{array}$ & $\begin{array}{l}\text { Make a Match, } \\
\text { Media Benda Asli, } \\
\text { Model Pembelajaran } \\
\text { Konvensional, Hasil } \\
\text { Belajar Siswa }\end{array}$ & $\begin{array}{l}\text { Pt. Mas } \\
\text { Suatnaya, Ign. } \\
\text { I } \quad \text { Wyn. } \\
\text { Suwatra, Wyn. } \\
\text { Suarjana }\end{array}$ & 16.50 & 21.50 & 5 \\
\hline 10. & $\begin{array}{l}\text { Pengaruh } \\
\text { Pembelajaran Kooperatif } \\
\text { Teknik Mencari Pasangan } \\
\text { (Make a Match) Terhadap } \\
\text { Hasil Belajar IPA Siswa } \\
\text { Kelas IV SD }\end{array}$ & 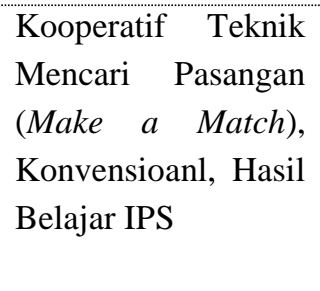 & $\begin{array}{l}\text { Ni. Pt. } \\
\text { Dayantari, } \\
\text { Ndara Tanggu } \\
\text { Renda, dan Ni. } \\
\text { Ngh. Madri } \\
\text { Antari }\end{array}$ & 18.81 & 23.46 & 4.65 \\
\hline & Model Pembelajaran & Make a Match & & 35.963 & 46.946 & 10.983 \\
\hline
\end{tabular}

Pada tahap ini dilakukan penggabungan 10 artikel yang akan dijadikan dasar dalam penelitian ini. Data yang disajikan pada Tabel 1 terdiri dari rata-rata sebelum dan sesudah dilakukan model pembelajaran Make a Match pada setiap data penelitian. Berdasarkan hasil analisis pada Tabel 1 menunjukkan bahwa terdapat pengaruh model pembelajaran Make a Match terhadap hasil belajar siswa. Hal ini dapat dilihat dari rata-rata sebelum menggunakan model pembelajaran Make a Match. Nilai rata-rata sebelum menggunakan model pembelajaran Make a Match yaitu sebesar 35.963 dan setelah menggunakan model pembelajaran Make a Match dapat meningkat yaitu sebesar 46.946. 
DOI : http://dx.doi.org/10.33578/jpfkip.v9i4.7995

ISSN : 2303-1514 | E-ISSN : 2598-5949

https://primary.ejournal.unri.ac.id/index.php/JPFKIP

Tabel 2. Paired Sample Statistics

\begin{tabular}{|c|c|c|c|c|c|}
\hline \multicolumn{6}{|c|}{ Paired Sample Statistics } \\
\hline & & Mean & $\mathbf{N}$ & $\begin{array}{c}\text { Std. } \\
\text { Deviation }\end{array}$ & Std. Error Mean \\
\hline Pair 1 & $\begin{array}{l}\text { Sebelum } \\
\text { Sesudah }\end{array}$ & $\begin{array}{c}36.00 \\
46.9000\end{array}$ & $\begin{array}{l}10 \\
10\end{array}$ & $\begin{array}{c}24.504 \\
29.86423\end{array}$ & $\begin{array}{c}7.749 \\
9.44393\end{array}$ \\
\hline
\end{tabular}

Pada Tabel 2. Paired Sample Statistic menunjukkan bahwa masing-masing penelitian yang telah dilakukan sebelumnya menunjukkan peningkatan yang signifikan terhadap hasil belajar siswa. Berdasarkan hasil perhitungan mean (M) skor rata-rata hasil belajar siswa sebelum menggunakan model pembelajaran Make a Match yaitu sebesar 36.00 sedangkan pada skor rata-rata hasil belajar siswa sesudah menggunakan model pembelajaran Make a Match yaitu sebesar 46.900.

Tabel 3. Paired Sample Correlations

\begin{tabular}{ccccc}
\hline \multicolumn{4}{c}{ Paired Sample Correlation } \\
\hline Pair 1 & N & Correlation & Sig. \\
\hline
\end{tabular}

Berdasarkan Tabel 3. Paired Sample Correlations menunjukkan bahwa adanya korelasi antara dua variabel yaitu model pembelajaran Make a Match dan hasil belajar siswa. Dikatakan adanya korelasi karena setelah diterapkan model pembelajaran Make a Match siswa menunjukkan peningkatan yang signifikan terhadap hasil belajar, berbeda dengan sebelum diberikan model pembelajaran Make a Match. Hasil dari korelasi tersebut sebesar 0.971 dengan sig. sebesar 0.000 . Dengan ini dapat disimpulkan bahwa korelasi antara kedua variabel sangat kuat dan signifikan.

Tabel 4. Paired Sample Test

\section{Paired Differences}

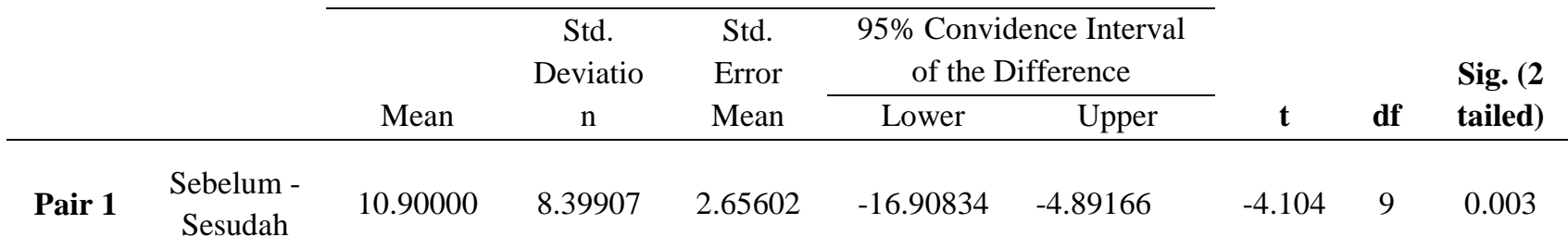

Pada Tabel 4 Paired Sample Test untuk mengetahui hipotesis pada penelitian ini menerima atau mendukung hipotesis dan menolak atau menggugurkan hipotesis. Dikatakan $\mathrm{H}_{0}$ apabila tidak ada pengaruh model pembelajaran Make a Match terhadap hasil belajar siswa sekolah dasar. Dan dikatakan $\mathrm{H}_{1}$ apabila ada pengaruh model pembelajaran Make a Match terhadap hasil belajar siswa sekolah dasar. Untuk mengetahui hipotesis tersebut ditolak atau diterima dapat dilihat pada nilai Sign. Jika nilai Sig. $>0.05$ maka $\mathrm{H}_{0}=$ diterima, dimana tidak ada pengaruh model pembelajaran Make a Match terhadap hasil belajar siswa. Dan jika nilai Sign. $<0.05$ maka $\mathrm{H}_{1}=$ diterima, dimana terdapat pengaruh model pembelajaran Make a Match terhadap hasil belajar siswa. Berdasarkan perhitungan pada Tabel 4 nilai sign. menunjukkan 0.003 , hal ini dapat 
disimpulkan bahwa terdapat pengaruh yang signifikan terhadap hasil belajar siswa antara

\section{Pembahasan}

Penelitian ini menggunakan model pembelajaran Make a Match. Dimana pada model pembelajaran ini siswa diajak untuk mencari pasangan sambil belajar mengenai suatu konsep atau topik dalam suasana yang menyenangkan. Model Make a Match adalah model pengajaran untuk me-review materi dengan menggunakan media kartu soal beserta kunci jawaban.

Model Make a Match ini memiliki kelebihan menurut Berlin (2015: 56) adalah sebagai berikut (a) mampu menciptakan suasana belajar aktif dan menyenangkan, (b) materi yang disampaikan lebih menarik perhatian siswa, (c) mampu meningkatkan hasil belajar siswa mencapai taraf ketuntasan belajar secara klasikal, (d) suasana kegembiraan akan tumbuh dalam proses pembelajaran, (e) kerjasama antar siswa terwujud dengan dinamis, dan (f) munculnya dinamika gotong royong yang merta di seluruh kelas.

Dalam penelitian ini dapat dikatakan terdapat pengaruh terhadap model pembelajaran Make a Match adalah apabila terdapat peningkatan yang dilihat dari hasil belajar siswa. Hasil belajar merupakan perubahan yang terjadi pada diri siswa, baik yang menyangkut aspek kognitif, afektif dan psikomotorik sebagai hasil dari kegiatan belajar. Aspek kognitif berkenaan dengan hasil belajar intelektual yang terdiri dari enam aspek, yakni pengetahuan, pemahaman, ingatan, aplikasi, analisis, dan evaluasi. Aspek afektif berkenaan dengan sikap yang terdiri dari lima aspek yaitu, penerimaan, jawaban atau reaksi, penilaian, organisasi dan internalisasi. Aspek psikomotorik berkenaan dengan hasil belajar keterampilan dan kemampuan bertindak. Ada enam aspek ranah psikomotorik yaitu, gerakan refleks, keterampilan gerakan dasar, kemampuan perseptual, keharmonisan atau ketepatan, gerakan keterampilan kompleks, dan gerakan ekspresif dan interaktif (Widiantono \& Harjono, 2017: 200). sebelum dan sesudah menggunakan model pembelajaran Make a Match.

Untuk mengetahui apakah hasil belajar yang dicapai telah sesuai dengan tujuan yang dikehendaki dapat diketahui melalui evaluasi. Evaluasi merupakan proses penggunaan informasi untuk membuat pertimbangan seberapa efektif suatu program telah memenuhi kebutuhan siswa. Selain itu, dengan dilakukannya evaluasi atau penilaian ini dapat dijadikan feedback atau tindak lanjut, atau bahkan cara untuk mengukur tingkat penguasaan siswa (Susanto, 2013: 5).

Penelitian terdahulu dari Saria, Sudana dan Gading (2017) bahwa hasil penelitian menemukan terdapat perbedaan yang signifikan hasil belajar IPA antara siswa yang mendapat perlakuan dengan model pembelajaran Make a Match dengan siswa yang tidak mendapat perlakuan dengan model pembelajaran Make a Match pada siswa kelas V SD. Adanya perbedaan yang signifikan menunjukkan bahwa pembelajaran menggunakan model Make a Match berpengaruh terhadap hasil belajar IPA dibandingkan dengan pembelajaran konvensional. Penelitian ini berbantuan peta pikiran. Penggunaan peta pikiran dalam pembelajaran membantu siswa memahami materi dengan mudah, karena peta pikiran dibuat dengan menggunakan gambar dan warna yang berbedabeda sehingga dapat menarik perhatian siswa untuk belajar. Dengan demikian, materi yang ada dalam peta pikiran lebih mudah dipahami dan lebih mudah untuk diingat oleh siswa sehingga hal tersebut dapat berpengaruh pada meningkatnya hasil belajar siswa.

Berdasarkan hasil penelitian pada 10 artikel yang dikaji terdapat peningkatan yang signifikan pada hasil belajar siswa yaitu sebesar 10,983 pada nilai sebelum dan sesudah diterapkan model pembelajaran Make a Match, hal tersebut dapat dilihat pada hasil SPSS versi 25 for windows menggunakan hasil analisis uji Paired Sample $T$ Test. Dengan begitu dapat disimpulkan bahwa 
DOI : http://dx.doi.org/10.33578/jpfkip.v9i4.7995

ISSN : 2303-1514 | E-ISSN : 2598-5949

https://primary.ejournal.unri.ac.id/index.php/JPFKIP

terdapat pengaruh model pembelajaran Make a

\section{SIMPULAN DAN REKOMENDASI}

Berdasarkan hasil penelitian pada 10 artikel yang dikaji yang dapat dilihat pada hasil penelitian menunjukkan bahwa terdapat perbedaan yang signifikan pada setiap artikel antara siswa yang belajar dengan model pembelajaran Make a Match dan siswa yang belajar secara konvensional. Dengan ini dapat disimpulkan bahwa model pembelajaran Make a Match berpengaruh positif terhadap hasil belajar siswa sekolah dasar.

Berdasarkan simpulan di atas, dapat diajukan saran-saran sebagai berikut. Kepada guru agar dapat menerapkan model pembelajaran Make a Match dalam proses pembelajaran, karena model pembelajaran Make a Match terbukti berpengaruh positif serta dapat meningkatkan hasil belajar siswa. Kepada siswa kedepannya untuk lebih memperhatikan dan memahami pembelajaran yang diberikan, agar dapat menambah wawasan pengetahuan pada setiap materi yang diberikan oleh guru. Kepada Kepala Sekolah dapat dijadikan

\section{DAFTAR PUSTAKA}

Anggarawati, A., Kristiantari, R., \& Asri, A.S. (2014). Pengaruh Make a Match Berbantuan Media Kartu Gambar Terhadap Hasil Belajar IPS SD. Jurnal Mimbar PGSD Universitas Pendidikan Ganesha Jurusan $P G S D, 2(1)$

Anggia, D, Asnawi, \& Juliati. (2019). Pengaruh Model Pembelajaran Make a Match Terhadap Hasil Belajar Siswa Pada Tema 7 "Peristiwa Dalam Kehidupan" SD Negeri 7 Langsa. Pendidikan Guru Sekolah Dasar Universitas Samudra. Journal of Basic Education Studies, 1(2), 57-67.

Arbiyah, Yati, \& Kurniawan, G. E. (2020). Pengaruh Model Pembelajaran Kooperatif Tipe Mencari Pasangan (Make a Match) Terhadap Hasil Siswa Pembelajaran IPA Pokok Bahasan Benda dan Sifatnya Kelas V SD Negeri 1 Weru Kidul Kecamatan Weru Kabupaten Cirebon. Jurnal Pendidikan Fisika dan Sains, 3 (1), 29-34
Match terhadap hasil belajar siswa.

pedoman dalam mengembangkan kegiatan pembelajaran pada setiap mata pelajaran guna meningkatkan hasil belajar siswa. Dan kepada peneliti yang akan melakukan penelitian serupa untuk menambah jumlah sampel yang akan diteliti agar hasil dari penelitian dapat digunakan untuk membandingkan serta menambah informasi tentang pengaruh model pembelajaran Make a Match terhadap hasil belajar siswa. Dengan menambah banyaknya data maka akan diperoleh data yang lebih objektif dan memberikan gambaran yang lebih luas.

Dan untuk meneliti lebih lanjut hendaknya mempertimbangkan faktor-faktor lain yang mungkin mempengaruhi penelitian. Hasil penelitian ini dapat memberikan referensi kepada peneliti lain dalam upaya menerapkan dan mengembangkan model pembelajaran yang bersifat inovatif kepada peserta didik.

Berlin, S., \& Imas, K. (2015). Ragam Pengembangan Model Pembelajaran Untuk Peningkatan Perfesionalitas Guru. Jakarta: Kata Pena.

Dayantari, N.P., Renda, N.T., \& Antari, N.N.M. (2013). Pengaruh Model Pembelajaran Kooperatif Teknik Mencari Pasangan (Make a Match) Terhadap Hasil Belajar IPS Siswa Kelas IV SD. Jurnal Pendidikan Universitas Pendidikan Ganesha, 1 (1)

Gading, K., Kharisma, K.D. (2017). Pengaruh Model Pembelajaran Kooperatif Tipe Make a Match Berbantuan Audio Visual Terhadap Hasil Belajar IPS Sekolah Dasar. Journal of Elementary Education Universitas Pendidikan Ganesha, 1 (2),153-160.

Kaharuddin, A. (2018). Keefektifan Model Make A Match dalam Pembelajaran Matematika Siswa Kelas VI Sekolah Dasar di Kecamatan Marioriwawo. Madrasah: Jurnal 
Pendidikan dan Pembelajaran Dasar, 11(1), 13-23.

Masa, N., Murda N., Mahadewi. L.P.P. (2017). Pengaruh Model Pembelajaran Make a Match Terhadap Hasil Bealajar IPS Siswa Kelas SD. Jurnal Mimbar PGSD Universitas Pendidikan Ganesha, 5(2), 1-10

Nadliyah, A., Taufiq, M., Hidayat, M.H., \& Kasiyun, S. (2019). Pengaruh Model Pembelajaran Kooperatif Tipe Make a Match Terhadap Hasil Belajar Siswa Pada Mata Pelajaran IPA. Jurnal PGSD Universitas Nahdlatul Ulama Surabaya, 2(1), .

Nisa, H. (2019). Pengaruh Model Pembelajaran Cooperative Learning Tipe Make a Match Terhadap Hasil Belajar Siswa Kelas IV Pada Mata Pelajaran IPA di MIN 1 Kec. Padang Hulu Kota Tebing Tinggi Tahun Ajaran 2018/2019. Skripsi. PGSD Universitas Islam Negeri, Medan.

Perdana, A.A. (2018). Pengaruh Model Pembelajaran Make a Match Terhadap Hasil Belajar Siswa Kelas IV SDN Semolowaru I Surabaya. Jurnal PGSD Universitas Negeri Surabaya, 6 (5), 640-649.

Saria, M.D., Sudana, D.N., \& Gading, K. (2017). Pengaruh Model Pembelajaran Kooperatif Tipe Make a Match Berbantuan Peta Pikiran Terhadap Hasil Belajar IPA Siswa Kelas V Sekolah Dasar. Jurnal PGSD Universitas Pendidikan Ganesha Mimbar PGSD, 5(2)

Saryono \& Rithaudin, A. (2011). Meta Analisis Pengaruh Pembelajaran Pendekatan Taktik (TgfU) Terhadap Pengembangan Aspek Kognitif Siswa Dalam Pendidikan Jasmani. Jurnal Pendidikan Jasmani Indonesia, 8(2)

Suarjana, M., Kusmariyatni, G.M.N. (2018). Pengaruh Model Pembelajaran Inkuiri Terbimbing Berbantuan Make a Match Terhadap Hasil Belajar IPA Siswa Kelas V SD. Jurnal Pendidikan Guru Sekolah Dasar Universitas Pendidikan Ganesha Singaraja, Indonesia.

Suatnaya, P.M., Suwatra, W., \& Suarjana, W. (2015). Pengaruh Model Pembelajaran Kooperatif Make a Match Berbantuan Media Benda Asli Terhadap Hasil Belajar Matematika Siswa Kelas IV. Jurnal PGSD
Universitas Pendidikan Ganesha Jurusan $P G S D, 3(1)$

Susanto, A. (2013). Teori Belajar dan Pembelajaran di Sekolah Dasar. Jakarta. Prenamadia Group.

Widiantono, N., \& Harjono, N. (2017). Penerapan Model Pembelajaran Interaktif Untuk Meningkatkan Aktivitas dan Hasil Belajar IPA Siswa Kelas 5 SD. Jurnal Pendidikan dan Kebudayaan, 7(3), 199-213.

Yulianti, K., Agung, G., Wibawa, M.C. (2017). Pengaruh Make a Match Berbantuan Kartu Teka-Tekii Terhadap Hasil Belajar IPS Siswa Kelas IV. Jurnal PGSD Universitas Pendidikan Ganesha Mimbar PGSD, 5(2) 